\title{
Caecal fermentation in rats fed diets containing transgenic potato tubers
}

\author{
J. Juśkiewicz, Z. Zduńczyk', S. Frejnagel and J. Fornal \\ Institute of Animal Reproduction and Food Research, \\ Polish Academy of Sciences \\ Tuwima 10, 10-747 Olsztyn, Poland
}

\begin{abstract}
Caecal fermentation in rats fed diets with $40 \%$ autoclaved potato tubers was examined. The potato tubers of the conventional cultivar, Irga, somaclone Irga, and four transgenic lines with genetically improved resistance to a necrotic strain of polato virus $Y\left(\mathrm{PVY}^{\mathrm{N}}\right)$ were compared. As regards the analysed indices, tubers of transgenic clone RIF (truncated gene coding PVY ${ }^{\wedge}$ polymerase in sense orientation), R2P (truncated gene coding PVY' polymerase in antisen.se orientation), and N'TR1.16 (non-translated regions of the PVY' genome in sense orientation) were similar to tubers of the conventional cultivar lrga. Tubers of transgenic clone NTR2.27 (non-translated regions of PVYN genome in antisense orientation) increased the amount of caecal digesta and production of SCFA compared with tubers of the conventional cultivar and other transgenic clones.
\end{abstract}

KEY WORDS: genetically modified potato, caccum, short-chain fatty acids, rat

\section{INTRODUCTION}

The first Polish transgenic clones resistant to a necrotic strain of potato virus $Y\left(P V Y^{N}\right)$ were obtained in the last decade (Chachulska et al., 1997). The results of our earlier studies indicate that genetically modified potato did not differentiate animal growth and feed utilization (Zduńczyk et al., 2004a) as well as serum enzymes and indices of non-specific defence of rats (Zduńczyk et al., 2004b), compared with non-transgenic tubers. The purpose of this study was to evaluate the potential influence of the transgenic potato on the fermentation processes in the caecum of rats.

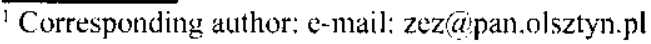




\section{MATERIAL AND MTHODS}

The transgenic lines of potato that were transformed with viral genome sequences in order to improve their resistance to a necrotic strain of potato virus $Y\left(P V Y^{N}\right)$ were prepared at the Institute of Biochemistry and Biophysics of the Polish Academy of Sciences (Chachulska et al., 1997). Four transgenic clones: RIF and R2P (transgenic lines with a truncated gene coding PVY ${ }^{\mathrm{N}}$ polymerase in sense or antisense orientation, respectively), NTR1.16 and NTR2.27 (transgenic lines with non-translated regions of $\mathrm{PVY}^{\mathrm{N}}$ genome in sense or antisense orientation, respectively) were compared with the conventional cultivar Irga and a non-transgenic somaclone (Irga w.t.). The autoclaved $\left(121^{\circ} \mathrm{C}, 1013 \mathrm{hPa}, 15 \mathrm{~min}\right)$ and dried $\left(40^{\circ} \mathrm{C}\right)$ potato tubers were introduced in a high amount $(40 \%)$ to diets, which were used in a 3-week feeding experiment on rats. Fach diet contained about $9.3 \%$ crude protein in air-dry matter $(5.3 \%$ of casein and $3.6 \%$ potato protein), potato and maize starch (about 27 and $36 \%$, respectively), and standard mineral and vitamin mixtures. Samples of fresh caecal digesta obtained from 8 animals in each group were analysed. The caecal $\mathrm{pH}$ was measured using a microelectrode and a $\mathrm{pH} / \mathrm{ION}$ meter (model 301, Hanna Instruments). The content of short-chain fatty acids (SCFA) was determined by gas chromatography (Shimadzu GC-14A with a $2.5 \mathrm{~m} \times 2.6 \mathrm{~mm}$ glass column, containing $10 \% \mathrm{SP}-1200 / 1 \% \mathrm{H}_{3} \mathrm{PO}_{4}$ on $80 / 100$ Chromosorb W AW, column temperature $110^{\circ} \mathrm{C}$, detector FID temperature $180^{\circ} \mathrm{C}$, injector temperature $195^{\circ} \mathrm{C}$ ). The results were statistically evaluated using one-way ANOVA and Duncan`s multiple range test.

\section{RESULTS}

The weight of caecal digesta of rats fed diets with tubers of transgenic clone NTR2.27 was significantly higher than in the groups receiving Irga w:t. and R1F (Table 1). The lowest hydration of caecal digesta was found in groups R2P and NTR1.16, while the highest was in group RIF. The highest amount of dry matter in the caecum was found in group NTR2.27. The caecal pH in group NTR1.16 increased, especially in comparison with non-transgenic Irga $w t$.

TABLE 1

Caccal parameters of rats fed diets containing conventional and transgenic potato tubers

\begin{tabular}{|c|c|c|c|c|c|c|c|}
\hline & \multirow{2}{*}{ Irga } & \multirow{2}{*}{ Irga $w: t$} & \multicolumn{4}{|c|}{ Irga - transgenic clone } & \multirow{2}{*}{ SEM } \\
\hline & & & $\mathrm{R} 1 \mathrm{~F}$ & $\mathrm{R} 2 \mathrm{P}$ & NTRI.16 & NTR2.27 & \\
\hline Caecal digesta, g & $0.98^{\operatorname{in}}$ & $0.90^{\mathrm{b}}$ & $0.87^{\mathrm{b}}$ & $0.95^{\text {si }}$ & $0.99^{\text {ih }}$ & $1.09^{n}$ & 0.02 \\
\hline Dry mater. $\%$ & $18.6^{\mathrm{ah}}$ & $18.7^{\mathrm{ath}}$ & $20.5^{a}$ & $17.6^{\mathrm{b}}$ & $18.0^{\mathrm{b}}$ & $19.3^{\text {abs }}$ & 0.29 \\
\hline Dry matter, g & $0.178^{\mathrm{h}}$ & $0.171^{\mathrm{b}}$ & $0.179^{\mathrm{b}}$ & $0.170^{\mathrm{h}}$ & $0.178^{\mathrm{h}}$ & $0.204^{a}$ & 0.01 \\
\hline $\mathrm{pH}$ of digesta & $6.99^{\mathrm{ah}}$ & $6.89^{\mathrm{h}}$ & $7.03^{\mathrm{ab}}$ & $7.08^{\text {ab }}$ & $7.21^{: 4}$ & $6.99^{4 h}$ & 0.04 \\
\hline
\end{tabular}

ath - values within cach row with the same superscript do not differ at $\mathrm{P} \leq 0.05$ 
The lowest concentration of SCFAs in the caecal digesta was found in group R2P, and the highest one, in group Irga w.t. (Table 2). A similar distribution of SCFA concentrations was also found for $\mathrm{C}_{2}, \mathrm{C}_{4}$ and $\mathrm{C}_{5}$ acids. No significant differentiation was observed in the concentrations of $\mathrm{C}_{3}$ acids in particular groups. The lowest values of the total SCFA pool size and of the major acids $\left(\mathrm{C}_{2}-\mathrm{C}_{4}\right)$ were found in the R2P group, while the highest values of the total SCFA pool and individual acids were determined in rats fed a diet supplemented with the NTR2.27 line.

TABLE 2

SCFA concentration $(\mu \mathrm{mol} / \mathrm{g})$ and $\mathrm{SCF} A \mathrm{~s}$ pool $(\mu \mathrm{mol} / 100 \mathrm{~g} \mathrm{BW})$ in the caecal digesta

\begin{tabular}{|c|c|c|c|c|c|c|c|}
\hline & \multirow{2}{*}{ Irga } & \multirow{2}{*}{ Irga $w: t$. } & \multicolumn{4}{|c|}{ Irga - Iransgenic clone } & \multirow{2}{*}{ SEM } \\
\hline & & & Rll: & $\mathrm{R} 2 \mathrm{P}$ & NTRI.16 & NTR2.27 & \\
\hline \multicolumn{8}{|l|}{ SCFA concentration } \\
\hline total & $66.07^{\text {at }}$ & $71.61^{\mathrm{a}}$ & $60.67^{\mathrm{h}}$ & $53.05^{\mathrm{c}}$ & $59.51^{\mathrm{bc}}$ & $67.82^{\mathrm{ab}}$ & 1.76 \\
\hline acetate $-\mathrm{C}_{2}$ & $47.63^{\mathrm{ab}}$ & $52.48^{\mathrm{a}}$ & $43.71^{\mathrm{kc}}$ & $38.31^{\mathrm{c}}$ & $42.65^{\mathrm{bc}}$ & $49.05^{\text {ab }}$ & 1.04 \\
\hline propionate $-\mathrm{C}_{3}$ & 8.83 & 8.64 & 8.39 & 7.45 & 8.48 & 8.71 & 0.19 \\
\hline isobutyrate $-C_{4 i}$ & $0.8 \mathrm{I}^{\mathrm{ith}}$ & $0.94^{4}$ & $0.94^{\prime \prime}$ & $0.65^{h}$ & $0.78^{\mathrm{ath}}$ & $0.89^{a}$ & 0.02 \\
\hline butyrate $-\mathrm{C}_{4}$ & $6.47^{\mathrm{a}}$ & $6.84^{\mathrm{a}}$ & $5.46^{\mathrm{ab}}$ & $4.75^{\mathrm{h}}$ & $5.32^{\text {ah }}$ & $6.62^{a}$ & 0.22 \\
\hline isovalerate $-\mathrm{C}_{\mathrm{si}}$ & $0.93^{\text {ah }}$ & $0.98^{\mathrm{ab}}$ & $1.00^{a}$ & $0.78^{\mathrm{b}}$ & $0.89^{\text {at }}$ & $0.94^{\mathrm{ab}}$ & 0.03 \\
\hline valerate $-C_{5}$ & $1.40^{1 w}$ & $1.73^{4}$ & $1.17^{\mathrm{ail}}$ & $1.11^{\mathrm{tt}}$ & $1.39 \mathrm{bc}$ & $1.61^{\mathrm{sh}}$ & 0.05 \\
\hline \multicolumn{8}{|l|}{$S C H A$ pool } \\
\hline total & $64.75^{\mathrm{ab}}$ & $64.45^{\mathrm{ab}}$ & $52.78^{\mathrm{tc}}$ & $50.40^{c}$ & $58.91^{\mathrm{ath}}$ & $73.92^{\circ}$ & 2.23 \\
\hline acetate $-C_{2}$ & $46.68^{\text {ab }}$ & $47.23^{\mathrm{ab}}$ & $38.03^{\text {he }}$ & $36.39^{\circ}$ & $42.22^{\text {ats }}$ & $53.46^{\mathrm{a}}$ & 1.62 \\
\hline propionate $-\mathrm{C}_{3}$ & 8.65 & 7.78 & 7.30 & 7.08 & 8.40 & 9.49 & 0.34 \\
\hline isobutyrate $-\mathrm{C}_{4 \mathrm{i}}$ & $0.79^{\mathrm{ab}}$ & $0.85^{\mathrm{a}}$ & $0.82^{\text {it }}$ & $0.62^{\mathrm{h}}$ & $0.77^{\mathrm{ab}}$ & $0.97^{\circ}$ & 0.03 \\
\hline butyrate $-\mathrm{C}_{4}$ & $6.34^{\mathrm{ab}}$ & $6.16^{\mathrm{ab}}$ & $4.75^{\mathrm{bc}}$ & $4.51^{\mathrm{c}}$ & $5.27^{\mathrm{abc}}$ & $7.22^{\mathrm{a}}$ & 0.28 \\
\hline isovalerate $-C_{s j}$ & 0.91 & 0.88 & 0.87 & 0.74 & 0.88 & 1.02 & 0.04 \\
\hline valerate $-\mathrm{C}_{5}$ & $1.37^{\mathrm{ab}}$ & $1.56^{\mathrm{a}}$ & $1.02^{\mathrm{r}}$ & $1.05^{\mathrm{h}}$ & $1.38^{\mathrm{a}}$ & $1.75^{\mathrm{a}}$ & 0.06 \\
\hline
\end{tabular}

\section{DISCUSSION}

The results of a few in vivo experiments of other authors (Hashimoto et al., 1999; Rogan et al., 2000; Zduńczyk et al., 2004a,b) indicate that tubers of potato with genetically improved virus- or insect-resistance were nutritional equivalents of their conventional counterparts. In the presented study tubers of the conventional cultivar Irga and transgenic clones R1F, R2P and NTR1.16 exerted a similar influence on the fermentation processes in the caecum of rats. However, a diet with tubers of transgenic clone NTR2.27 significantly increased the amount of caecal digesta, dry matter content and total SCFA pool. This may point to decreased utilization of nutrients (mainly starch) in the upper part of the gastrointestinal tract and/or to an increase in the activity of caecal microflora in 
this group of rats. The results obtained in a relatively short feeding experiment ( 3 weeks) are insufficient to explain the reasons for the determined differences: increased bulk of caccal digesta and total SCFA pool in group NTR2.27, as well as the highest hydration of caecal digesta in group R1F.

\section{CONCLUSIONS}

As regards their influence on caecal fermentation processes in rats, tubers of transgenic clone R1F, R2P, and NTR 1.16 were similar to tubers of the conventional cultivar Irga. In contrast, tubers of transgenic clone NTR2.27 increased the bulk of caecal digesta and production of SCFA.

\section{RFFFRENCES}

Chachulska A.M., Chrzanowska M., Flis B., Krzymowska M., Lipska-Dwužnik A., Robaglia C., Zagórski W., 1997. Potato and tobacco cultivars transformation towards potato virus resistance. Biotechnologia 4. 48-54

Hashimoto W., Momma K., Yoon H.J., Orawa S., Ohkawa Y., Ishige T., Kito M., Utsumi S., Murata K., 1999. Safety assessment of transgenic potatoes with soybean glycinin by feeding studies in rats. Biosci. Biolech. Biochem. 63, 1942-1946

Rogan (i.J., Bookout J.T., Duncan D.R., Fuchs R.L., Lavrik P.B., Love S.L., Mucth M., Olson T., Owens E.D., Raymond P.J., 7alewski J., 2000. Compositional analysis ol tubers lrom insect and virus resistant potato plants. J. $\Lambda$ gr. Food Chem. 48, 5936-5945

Zdunczyk Z., Frejnagel S., Fonnal J., Flis M., Palacios M.C., Flis B., Zagórski-()stoja W., $2004 a$. Biological response of rat led diets with high tuber content of conventionally bred and transgenic potato resistant to necrotic strain of potato vinus (PVY). Part. I. Chemical composition of tubers and nutritional value of diets. Food Control, http:/www.sciencedirect.com (in press)

Zduńczyk 7.., Juśkiewicz J., Fornal J., Mazur-Gonkowska B., Koncicki A., Flis B., ZimnochGuzowska E., Zagórski-Ostoja W., 2004b. Biological response of rat fed diets with high tuber content of conventionally bred and transgenic potato resistant to necrotic strain of potato virus $\left(P V Y^{N}\right)$. Part. II. Caecal melabolism, serum enzymes and indices of non-specific defence of rats. Food Control, http:/www.sciencedirect.com (in press)

\section{STRLSZCZENIF}

\section{Fermentacja $w$ jelicie ślepym szczurów żywionych dietami z bulwami ziemniaków linii} trangenicznych

Porównano wpływ diet z zawartością $40 \%$ autoklawowanych bulw ziemmiaków konwencjonalnej odmiany Irga, bulw $z$ hodowli in vitro oraz czterech klonów transgenicznych o genetyc nie zwiększonej odporności na nekrotycany szczep wirusa $\mathrm{Y}$ zicmniaków (PVY ${ }^{N}$ ) na procesy fementacyjne $w$ jelicie ślepym szczurów. Pod w7ględem analizowanych kryteriów bulwy klonu RIF i R2P (z wstawką niekomplenego genu kodujacego I'VY' polimerazc, odpowiednio $\mathrm{w}$ orientacjii sens $\mathrm{i}$ antyens) oraz. klonu N'TR1.16 ( $\angle$ wstawka fragmentu cDNA wirusa PVYא w orientacji sens) byly podobne do bulw konwencjonalncj odmiany Irga. Bulwy klonu N'lR2.27 (z wstawką fragmentu cDNA wirusa PVY* w orientacji antusens) zwiększały ilość treści jclita i produkcje LKT w porównaniu z bulwami odmiany konwencjonalnej. 